Przegląd Prawa Konstytucyjnego

------ISSN 2082-1212-------

DOI 10.15804/ppk.2017.06.01

$-\mathrm{Nr} 6(40) / 2017--------$

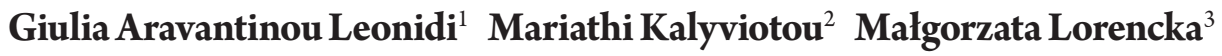

\section{Political System Changes in Greece after the 2015 General Election}

Keywords: party system change, electoral system reform, constitutional reform, Greece Słowa kluczowe: zmiana systemu partyjnego, reforma systemu wyborczego, reforma konstytucji, Grecja

\section{Summary}

The article analyzes the political changes that have taken place in Greece following a double parliamentary election of 2015 (in January and September), focusing on three levels: 1) party system change, 2) electoral system change into parliament, 3) constitutional reform. The first part of the text sets out the basic changes in the structure of the party system, emphasizing the electoral victory of the radical forces - the far left populist SYRIZA or the rise of the far-right (Golden Dawn) in the double election of 2015.

The paper also briefly reviews the nature and functioning of the Greek parliamentary electoral system with special regard to the newly adopted electoral law. In this respect, the paper highlights the main constitutional principles governing suffrage, as a necessary background to examining and understanding the framework upon which Greek electoral systems are based. It also presents the main features of the current electoral system,

1 The Author is a post-doctoral research fellow in Comparative Constitutional Law, Department of Political Science, University La Sapienza of Rome, Italy. E-mail: giulia.aravantinouleonidi@uniromal.it.

2 The Author is a PhD in the Scientific Council of the Hellenic Parliament (Scientific Service of the Hellenic Parliament), Greece. E-mail: m.kaliviotou@parliament.gr.

3 The Author is a PhD in the Chair of Political Systems of Highly Developed States of the Institute of Political Sciences and Journalism of the University of Silesia in Katowice, Poland. E-mail: malgorzata.lorencka@us.edu.pl. 
since it is the one to be applied in the following parliamentary election. The focus will be then on the recent reform of the electoral system in Greece after the adoption of Law 4406/2016. The paper analyses its most significant aspects and raises a number of relevant questions. Special reference is made to the voting procedure followed by the Greek Parliament for the adoption of Law 4406/2016, since it is a key factor for its enforcement.

Since the outbreak of the crisis discussions about constitutional reform have been ongoing in Greece, although the initiation of a formal amendment process was blocked until 2013, due to the time-constraints imposed by the constitutional amending formula. The paragraph assesses the proposals made in July 2016 by the Tsipras government for a radical revision of the 1975 Constitution, taking into account the intense debate which engaged Greek constitutional law scholars. The Author highlights the particular features of the Greek constitutional revision model, characterized by political-elite-driven change which has led in the past to amending attempts lacking of a broad consensus. The broad scope of the proposed amendments requires political foresight and caution to prevent the constitutional revision from being reduced to a mere political diversion to ensure the permanence in power of certain political actors in the absence of consent and to deflect attention from continued controversial austerity policies.

\section{Streszczenie}

\section{Zmiany w systemie politycznym w Grecji po wyborach powszechnych w 2015 r.}

Artykuł analizuje zmiany polityczne, jakie zaszły w Grecji po podwójnych wyborach parlamentarnych z 2015 r. (w styczniu i wrześniu), koncentrując się na trzech płaszczyznach: 1) zmiany modelu systemu partyjnego, 2) zmiany systemu wyborczego do parlamentu, 3) reformy konstytucji. W pierwszej części tekstu określono podstawowe zmiany w strukturze systemu partyjnego, podkreślając zwycięstwo wyborcze radykalnych ugrupowań lewicowej Syrizy czy skrajnej prawicy (Złoty Świt) w podwójnej elekcji z 2015 r.

W drugiej części artykułu została omówiona charakterystyka i sposób funkcjonowania greckiego parlamentarnego systemu wyborczego, ze szczególnym uwzględnieniem nowo przyjętej ordynacji wyborczej. Zwrócono uwagę na główne zasady konstytucyjne dotyczące prawa wyborczego, jako niezbędnego tła dla zbadania i zrozumienia ram, na których opierają się greckie systemy wyborcze. Przedstawiono główne cechy obecnego systemu wyborczego na podstawie ostatniej reformy systemu wyborczego w Grecji, ustawy no. 4406 z 2016 r. Artykuł analizuje jego najważniejsze aspekty i porusza szereg istotnych pytań. Odwołuje się szczególnie do procedury głosowania prowadzonej przez grecki parlament w celu przyjęcia ustawy 4406/2016, ponieważ jest to kluczowy czynnik jej egzekwowania. 
Ostatnia część artykuły została poświęcona planowej zmianie greckiej konstytucji. Od wybuchu kryzysu gospodarczego w Grecji trwają dyskusje na temat reformy konstytucyjnej, chociaż proces formalnej zmiany został wstrzymany do 2013 r., ze względu na ograniczenia czasowe narzucone w konstytucji. W artykule dokonano oceny propozycji złożonych przez rząd Tsiprasa w lipcu 2016 r. w celu radykalnej rewizji konstytucji z 1975 r. Autorka podkreśla szczególne cechy greckiego modelu rewizji konstytucyjnej, charakteryzującego się zmianami kierowanymi przez elitę polityczną, które doprowadziły w przeszłości do zmian bez większego konsensusu. Szeroki zakres proponowanych poprawek wymaga politycznego przewidywania i ostrożności, aby zapobiec przekształceniu rewizji konstytucji w zwykłą zmianę polityczną oraz aby zapewnić ciągłość władzy niektórych podmiotów politycznych przy braku zgody i odwrócić uwagę od wciąż kontrowersyjnych polityk oszczędnościowych.

I.

Radicalizasion of public sentiment as the economic crisis deepened was bound to contribute to a change in the support for political parties after the 2008. The conservative parties of New Democracy and the Panhellenic Socialist Movement (PASOK) formed in 1974 after the fall of the Black Colonels dictatorship led to the creation of a dual-party system which had not left much room for other parties, such as the Communist Party of Greece or the right-wing Popular Orthodox Rally (LAOS) and smaller groups that formed the Synaspismos coalition, later to be called the Syriza ${ }^{4}$. The deepening economic crisis of 2008 and the social and economic effects it caused led to the transformation of the Greek political scene at the expense of its destabilisation and fragmentation. The two leading parties were mainly blamed for the deteriorating living conditions, with most of the criticism falling on PASOK, which had won the elections in 2009 and had negotiated the first international assistance programme. Despite numerous pro-

4 M. Lorencka, Influence of the economic crisis on the functioning of the political systems in Greece, [in:] T. Kubin, M. Lorencka, M. Mysliwiec, Impact of economic crisis on functioning of political systems. A case study of Greece, Spain, and Italy, Katowice 2017, pp. 105-114. 
tests and riots, on 6 May 2010, the socialists adopted anact accepting the financial aid package.

The extent of social discontent and the necessity of further financial assistance made the Prime Minister Jorgos Papandreou (grandson and son of Greek prime ministers) announce a referendum to decide on this matter, however, several days later, he withdrew from the idea and submitted his resignation on 11 November 2011. The president Karolas Papoulias stated that the objective of the new government would be to hold new elections after negotiation of the next international assistance package. The nonpartisan technocrat Lucas Papadimos, former vice-president of the European Central Bank, was elected as prime minister with the support of PASOK and New Democracy. The next financial assistance package was accepted in February of 2012. A strong division developed, consisting of parties supporting the assistance programmes, such the PASOK or New Democracy and into anti-memorandum groups (groups opposing the bailouts), such as the Syriza, the Radical Left Party or the Golden Dawn, an extreme right-wing party formed in 1993, which had never previously entered parliament, as it had failed to reach the required 3\% threshold. In the meantime, many divisions appeared within individual parties as well. Dora Bakoyannis left the New Democracy party to form the liberal-conservative Democratic Alliance party. In 2012, Panos Kammenos left the same party to establish the Independent Greeks party and in 2010, a group of former Eurocommunism supporters left the Syriza to form the Democratic Left (DIMAR). Significant changes also took place inside the parties. Syriza, which was formed in 2004, a coalition of a dozen or so radical groups, replaced their leader. In 2010, Alekos Alavanos (born in 1950, a former member of the Greek Communist Party) was replaced with the 36-year-old Alexis Tsipras. The main slogans of the party include unity and radicalism and opposition to any form of coalition with the socialists or reformists. Another milestone in Syriza's activity was its transformation from a loose coalition of political groups into a political party during the founding congress held on 10-14 July 2013. Alexis Tsipras was re-elected as party secretary in the primaries. The party itself constituted a blend of different ideologies (from anticapitalism, Trotskyism, through various communist and socialist ideologies to feminism). 
The New Democracy won the 2007 elections with over $41 \%$ of votes, whereas in 2009 , the socialist PASOK came out victorious with over $43 \%$ of support. Both the parties formed single-party cabinets. They won the majority in parliament thanks to a 40 -seat bonus given, in principle, to the victorious party, a regulation that was introduced into the proportional electoral system. In 2008, the majority bonus was increased to 50 seats. These elections were characterised by two-party competition.

The geopolitical situation was relevantly altered by the elections of 6 May and 17 June 2012. The double parliamentary elections were the result of the inability to appoint a government. They were also a sign of protest against austerity. The electoral volatility index reached its highest value in history 48.7 (May 2012), which means that every other voter changed his or her electoral preferences. Seven political groups entered parliament. Although the New Democracy won both the elections, its support in May reached 18.85\%, while in June it was $29.66 \%$ (caused by a fear that Syriza might win). The runner-up was the radical left, achieving $16.79 \%$ of votes in May and $26.89 \%$ in June. PASOK suffered the greatest defeat. It received $13 \%$ of votes in May and $12.28 \%$ in June. For the first time in history, the neo-fascist Golden Dawn party managed to enter into parliament with a result of almost $7 \%$ of votes. This far right party founded by Nikolaos Michaloliakos, uses symbols that appear to be similar to those used by the NSDAP (the party's meander symbol with the same colours as the NSDAP flag).

In 2012, new parties managed to enter into parliament, including the leftwing DIMAR or the nationalist Independent Greeks party. Their presence will be of significance in the context of creating political coalitions following the dual elections of 2012 and 2015. The only time the Greeks had to form a coalition was in 1989, which means that a new standard of competition and cooperation developed between political parties. After the 2012 elections, Antonis Samaras from the New Democracy became the prime minister, and formed a coalition with PASOK and DIMAR.

The next early parliamentary elections took place on 25 January 2015 because of the inability of the Chamber of Deputies to elect the President of the Republic, and on 20 September 2015 because of the division that had formed in the Syriza as a result of the acceptance in July of the 3rd assistance programme. The above elections had one victor - the party of Alexis Tsipras, who 
became the prime minister. In January, Syriza received the support of $36.34 \%$ of voters, while in September - 35.34\%. It was, however impossible to win a majority of seats in the parliament, that is why a coalition was formed with the nationalist party of Independent Greeks. This rather exotic political coalition was formed on the grounds of both the parties' opposition to the conditions of the memoranda.

II.

The legal rules regulating the parliamentary electoral system in Greece are laid down either in the Constitution of Greece ${ }^{5}$ or in ordinary laws (and, by legislative delegation, general regulatory administrative acts, namely presidential decrees and ministerial decrees).

The main general principles for the composition of the Hellenic Parliament and the electoral procedure for the election of its Members are formulated in Art. 51-57 of the Constitution. While these provisions contain rules on issues regarding, inter alia, the principle of free and unfalsified expression of the popular will, as an expression of popular sovereignty (Art. 52), the principles of direct, universal, $\operatorname{secret}^{6}$ (Art. $51 \S 3$ ) and compulsory ${ }^{7}$ (Art. $51 \S 5$ ) suffrage, the principle of simultaneous elections (Art. $51 \S 4$ ), the minimum (two hundred Members of Parliament, hereafter MPs) and maximum (three hundred MPs) number of MPs (Art. $51 \S 1$ ), the duration of the parliamenta-

5 The Constitution of Greece translated in English, French and German is available at: http://www.parliament.gr/en/Vouli-ton-Ellinon/To-Politevma/Syntagma (26.09.2016).

6 The jurisprudence of the Special Supreme Court (see Decisions no. 48/1978, 35/1982, $11,12,13 / 1994,58 / 1995,34 / 1999$ and others) and also the legal theory (see, among others, Pr. Dagtoglou, Constitutional Law, Human rights, $3^{\text {rd }}$ ed., Athina-Komotini 2010, pp. 1209 ff., Ph. Vegleris, The particular nature of electoral law, Athina-Komotini 1992, p. 51) have recognized that the principle of the equality of the vote derives implicitly from the Constitution of Greece (see Art. 4\$1, 2 which guarantees the general principle of equality, and Art. $1 \$ 2$, which sets out the democratic principle). Prof. K. Mavrias, Constitutional Law, 5th ed., Athens 2014, pp. 380-382) takes the view that the principle of the equality of the vote, either explicitly or implicitly grounded in the Constitution, does not necessarily leads to the application of the equivalence of the vote.

7 The Constitutional Revision of 2001 implicitly prohibits the imposition of criminal sanctions for not voting. 
ry period (four consecutive years) and the substitution of the MPs (Art. 53), the qualifications (Art. 55), the disqualifications (Art. 56) and the incompatibilities (Art. 57) for MPs, etc., they do not set the electoral system ${ }^{8}$.

Article $54 \$ 1^{9}$ of the Constitution of Greece grants the ordinary legislator $^{10}$ the competence to choose an electoral system "after taking into account the current political conditions"11, so that adaptability to the changing political and social circumstances (and the consequent goal of governmental stability) is achieved ${ }^{12}$. The wide discretion of the legislator to choose an electoral system is limited by the general principles of state ${ }^{13}$ and the above mentioned constitutional principles governing suffrage ${ }^{14}$.

The general pattern of almost ${ }^{15}$ all systems used in Greek parliamentary elections after 1974 was the so-called 'ameliorated' or 'reinforced' propor-

8 K. Chryssogonos, Electoral system and Constitution, Athina-Komotini 1996, pp. $36 \mathrm{ff}$.

9 See Art. 54\$ 1 of the Constitution of Greece: "The electoral system and constituencies are specified by statute $[. .$.$] ".$

10 Unlike the constitutions of other European countries (for example, Austria, Sweden and Portugal), see the Report of 18.07.2016 of the Scientific Service of the Hellenic Parliament on the Bill "Proportional representation of political parties, extension of the right to vote and other provisions concerning the election of Members of the Parliament" (Law no. 4406/2016, Official Gazette 133 A/26.07.2016), rapporteur: D. Kanellopoulos, www. hellenicparliament.gr/UserFiles/7b24652e-78eb-4807-9d68-e9a5d4576eff/analeklog-epist. pdf (9.10.2016). According to Art. $65 \$ 5$ and $74 \$ 1$ of the Constitution of Greece and Art. 162 \ 3 subpar. a' of the Hellenic Parliament's Standing Orders, the Scientific Service of the Hellenic Parliament is responsible, inter alia, for the scientific elaboration of Bills for the Plenum. Its Report contains the results of the scientific elaboration of Bills, including, among others, in-depth study on the most significant arising legal issues, detailed comments on the compatibility of the proposed provisions with the constitutional rules, the EU and the international law, extended research on legal bibliography and case law of the domestic, EU and international courts, etc.

11 See Decision no. 12/1994 of the Special Supreme Court.

12 See K. Chryssogonos, An introduction to Greek electoral law, http://www.cecl.gr/rigasnetwork/databank/REPORTS/r8/GR_8_Chryssogonos.html (9.10.2016).

13 See E. Venizelos, Lessons of Constitutional Law, Athina-Komotini 2008, pp. 485 ff., G. Papadimitriou, Electoral system and governance system, [in:] Electoral system and form of government, Athina-Thessaloniki 2007, pp. 19-28, K. Chryssogonos, Electoral system..., pp. 159-298.

14 See Decisions no. 4, 11, 14/1994, 12/1994 of the Special Supreme Court.

15 The sole exception was the proportional system (simple proportionality) used in the three consecutive elections of 1989 and 1990, which reduced the first party premium to a minimum, causing thereby governmental instability for several months. 
tional system, which gives the first party a considerably higher share of parliamentary seats than its share of votes is ${ }^{16}$.

The current electoral system of Greece is set by Law 3231/2004 as it is amended by the Law 3636/2008. Principal characteristics of this electoral system are the following:

The MPs are elected according to the results of votes of their political party in each district (the party candidates are selected by voters within the party list of their choice by marking a cross next to the name of the candidate(s) of their choice ${ }^{17}$ ), except twelve (12) State Deputies, who, according to Art. $54 \S 3$ of the Constitution ${ }^{18}$, are elected in proportion to the total number of votes of their party throughout the country, according to a party-list proportional representation system, the whole country then being regarded as one constituency.

A parliamentary majority can be achieved and a government formed even if the winning party fails to secure a simple majority of the valid votes. This outcome is made possible by awarding extra representation (essentially a bonus) to the larger parties that obtain more than a minimum percentage of the national vote. This electoral system grants the winning political party (or coalition of parties $\left.{ }^{19}\right)$ a majority premium of fifty $(50)^{20}$ seats $^{21}$. Consequent-

16 This happens at the expense of smaller parties. See K. Chryssogonos, An introduction...

17 The number of crosses varies from one to five depending on constituency size. Ballots with no. crosses or more crosses than allowed, count for only the party but not the individual candidates.

18 See Art. 54\$ 3 of the Constitution of Greece.

19 The majority bonus is awarded to a coalition of parties provided that the mean share of the vote of the coalition parties is greater than the vote share of the single party with the largest number of votes (see Law 3636/2008 Art. 1 amending Law 3231/2004 Art. 6 \$ 1 and 2).

20 Law 3231/2004 was less favorable for the plurality party, as only forty (40) additional seats were reserved for them. Law 3636/2008 increased the number of bonus seats from forty (40) to fifty (50).

21 For the relevant constitutional issues, see, among others, the Report of 21.01.2008 of the Scientific Service of the Hellenic Parliament on the Bill "Amendment of the Law 3231/2004 «Election of Members of the Parliament»" (Law 3636/2008, Official Gazette 11 A/01.02.2008), rapporteur: D. Kanellopoulos, http://www.hellenicparliament.gr/UserFiles/7b24652e78eb-4807-9d68-e9a5d4576eff/eklogi-epis.pdf (9.10.2016), Ch. Anthopoulos, The control of constitutionality of the electoral laws in Greece and the unconstitutionality of the current electoral system, "Efimerida Dioikitikou Dikaiou” 2015, pp. 559-574. 
ly, only the two hundred fifty (250) seats out of the three hundred (300) total are distributed to all the parties under the proportional system. It should be noted that the various reinforced systems applied since 1974 in Greece vary only in the relative advantage that each version has bestowed upon the top two or three parties ${ }^{22}$.

Parties, coalitions of parties and independent candidates are required to garner at least three percent (3\%) of the total share of the vote nationally in order to be represented in parliament ${ }^{23}$.

The protest votes (white or blank-ballots) are not counted as valid. They are added to the number of void votes and are not considered during the seats distribution ${ }^{24}$.

\section{III.}

On 21.07.2016 the Plenum of the Hellenic Parliament adopted the Law no. 4406/2016 "Proportional representation of political parties, extension of the right to vote and other provisions concerning the election of Members of the Parliament"25. Law 4406/2016 amended the previous Law 3231/2004 ${ }^{26}$

22 See M. Mendrinou, The electoral policy in the Greek political system: internal and external aspects, 1974-2000, Athina 2000, pp. 75-87, C. Lamprinakou, Electoral System Change in Europe since 1945: Greece, https://www.google.gr/url?sa=t\&rct=j\&q=\&es$\mathrm{rc}=\mathrm{s} \&$ source $=$ web \&cd=9\&cad $=\mathrm{rja} \& \mathrm{uact}=8$ \&ved $=0 \mathrm{ahUKEwjSjZf5u} 83 \mathrm{PAhVMth}-$ QKHRiIAB 4QFghdMAg\&url=http\%3A\%2F\%2Fwww.electoralsystemchanges. eu\%2FFiles\%2Fmedia\%2FMEDIA_199\%2FFILE\%2FGreece_summary.docx\&usg=AFQjCNGa4TWp9XuO8KRJYLMsVZGCwotfVA\&bvm=bv.135258522,d.bGg (9.10.2016).

23 Law 3231/2004, Art. 5. The 3\% threshold was considered by the Special Supreme Court as compatible with the rules of the Constitution of Greece, see Decisions no. 19/2010, $34 / 1999,74 / 1997,11 / 1994$, and others. As a consequent, the larger the number of votes for parties that do not reach this 3\% threshold, the lowest the number of votes required for the first party to secure an absolute majority (of 151 seats) in parliament.

See Law 3434/2006 (Official Gazette 21 A/07.02.2006) Art. 1. See also Special Supreme Court Decision no. 34/1999 (contra: Decision no. 12/2005).

24 See Law 3434/2006 (Official Gazette 21 A/07.02.2006) Art. 1. See also Special Supreme Court Decision no. 34/1999 (contra: Decision no. 12/2005).

25 Official Gazette $133 \mathrm{~A} / 26.07 .2016$.

26 Official Gazette 45 A/11.02.2004. 
(as it was amended by the Law 3636/2008). This is the sixteenth parliamentary electoral system since $1926^{27}$ and the eighth since $1974^{28}$. Law 4406/2016 Art. $2 \$ 2$ repealed Art. $6 \$ 2$ and 3 of Law 3231/2004 (as they were amended by the Law 3636/2008 Art. 1). Therefore, the 50 seats majority bonus to the party that obtain the plurality of valid votes was repealed. At the same time, Law 4406/2016 Art. $2 \$ 1$ point a. amended Art. $6 \$ 1$ of Law 3231/2004 (as it was amended by the Law 3636/2008 Art. 1) by increasing the multiplication factor from two hundred and fifty (250) in three hundred (300). This means that the total number of valid votes polled by each combination nationally is multiplied by 300 (instead of 250).

By this reform, the reinforced proportional system is retained but it will function under a new variation: the representation of the political parties becomes more proportional. In this respect, the new electoral system takes us back to the electoral Law 1907/199029. In other words, the reinforced proportional system becomes as it was set before Law 3231/2004, where the bonus award was first introduced.

One of the main subjects that dominated the debate of the bill (which became then the Law 4406/2016) in the Plenum of Parliament was the strong concerns regarding the issue whether the repeal of the bonus would lead to weak formations of governments and continuing elections and, even worse, to political instability and a vulnerable state ${ }^{30}$. Among the many interesting aspects of that issue, one can distinguish the constitutional approach.

27 In 1926 the country abandoned majority voting, conducted through dropping lead balls in a ballot box, see R. Clogg, Greece, [in:] Democracy and Elections: Electoral Systems and Their Political Consequences, eds. V. Bogdanor, D. Butler, Cambridge 1983, p. 190. See also A. Pantelis, The Greek electoral systems and the elections (1926-1985) on the computer, Athens 1988.

28 Following the collapse of the military government, known as Colonels' regime (1967-1974), an appointed interim government of prominent politicians (known as "National Unity Government") undertook the task of the democratisation of the Greek state and the declaration of the Third Hellenic Republic.

29 Official Gazette 163 A/39.11.1990.

30 See the Minutes of Hellenic Parliament's sittings of 19.07.2016, 20.07.2016 and 21.07.2016, available in Greek at: http://www.hellenicparliament.gr/Praktika/Synedriaseis-Olomeleias?sessionRecord=b4588e74-e242-4b1a-9e39-a649001b12b3 (9.10.2016) http:// www.hellenicparliament.gr/Praktika/Synedriaseis-Olomeleias?sessionRecord=4bc3244b-0 a8d-4b18-be91-a64a00a02629 (9.10.2016) and http://www.hellenicparliament.gr/Praktika/ Synedriaseis-Olomeleias?sessionRecord=9ee047ee-34c1-4b42-9cf8-a64b0025fce0 (9.10.2016). 
As it has already been mentioned above, the Constitution of Greece does not set the electoral system ${ }^{31}$. Therefore, the electoral system may pursue both the aim of accurate representation of political forces in Parliament, and the aim of safeguarding governmental stability. Both aims are within the constitutional spectrum ${ }^{32}$. The appropriate and adequate mix lies with the ordinary legislator. On the basis of the above, it may be concluded that only extreme legislative options would be considered violating the Constitution ${ }^{33}$.

It is, however, common throughout Greek electoral systems that the aim of governmental stability is consolidated over the equivalence of the vote ${ }^{34}$. In the past, the constitutionality of some variations of the reinforced proportional electoral system of Greece has been challenged. The Electoral Court and the Special Supreme Court never detected a violation of the constitutional principles governing the vote and the suffrage ${ }^{35}$.

Law 4406/2016 Art. 1 amended Art. $4 \$ 1$ of Presidential Decree 26/2012 ${ }^{36}$ by setting the minimum voting age to seventeen (17), instead of eighteen (18) ${ }^{37}$.

It is worth nothing that by virtue of Art. $51 \$ 3$ of the Constitution of Greece the minimum age of the electorate is determined by law: "The Members of

\footnotetext{
31 See Art. $54 \$ 1$ of the Constitution of Greece.

32 See Art. $1 \S 2-3,4 \S 1-2$ and $41 \S 1$ of the Constitution of Greece.

33 See E. Venizelos, op.cit, pp. 485 ff.
}

34 See K. Mavrias, op.cit, p. 433, E. Venizelos, op.cit., pp. 486 ff., N. Kalogirou, Parliamentary republic and electoral system, Athina-Komotini 1989, pp. 16-21. For the governmental stability as a constitutional principle, see K. Chryssogonos, Electoral system..., pp. $440 \mathrm{ff}$.

35 See Decisions no. 20, 30, 31/1951, 13/1958 of the Electoral Court and Decisions no. 48/1978, 36, 39/1990, 11, 12, 13/1994, 23, 24, 25, 51,74/1997 of the Special Supreme Court. See also the Report of 18.07.2016 of the Scientific Service of the Hellenic Parliament on the Bill "Proportional representation [...]" (Law no. 4406/2016), p. 7 and the citations it refers to: A. Raikos, The control of the validity of the elections of $20^{\text {th }}$ November $1977,1^{\text {st }}$ complement of procedural electoral law, 1983, pp. $60 \mathrm{ff}$., A. Raikos, The control of the validity of the parliamentary and European parliamentary elections, $4^{\text {th }}$ Complement of procedural electoral law, 1993, pp. $125 \mathrm{ff}$., A. Raikos, The control of the validity of the parliamentary and European parliamentary elections, $5^{\text {th }}$ Complement of procedural electoral law, 1996, pp. $153 \mathrm{ff}$., A. Raikos, The control of the validity of the elections of $22^{\text {nd }}$ Septempter 1996, $6^{\text {th }}$ Complement of procedural electoral law, 1999, pp. 250 ff. See also K. Chryssogonos, Electoral system..., pp. 332-342.

36 Official Gazette 57 A/15.03.2012.

37 It is interesting to note that, according to Art. $4 \$ 2$ of Presidential Decree 26/2012, "for the purpose of the previous paragraph, the 1st January is considered to be the date of birth of all who were born in that year". 
Parliament shall be elected [...] by the citizens who have the right to vote, as specified by law The law cannot abridge the right to vote except in cases where a minimum age has not been attained [...]"38. Prior to the publication of Law $4406 / 2016$, the right to vote was granted (by Law $1224 / 1981^{39}$ ) to individuals who were at least eighteen years old (or would turn eighteen on the year of the election) ${ }^{40}$. That meant that the minimum voting age was (more or less) equal to that of reaching adulthood.

Although on the one hand, the Constitution of Greece does not create obstacles for the reduction of the voting age, and on the other hand, Greece is not the first country to grant the right to vote to parliamentary elections to individuals who are less than eighteen years old ${ }^{41}$, the reduction of the minimum voting age to seventeen by Law 4406/2016 raises some questions. For example, according to Art. 127 of the Civil Code of the Hellenic Republic, only eighteen years old man/woman possesses unlimited legal capacity. According to Art. $64 \$ 1$ of the Greek Code of Civil Procedure she who does not possess unlimited legal capacity cannot stand before civil courts in her own name (she is represented by her legal representatives). In that context the right to vote in an age under the age of majority seems rather inconsistent.

It is interesting to highlight that some parts of the voting procedure of Law $4406 / 2016$ are of considerable importance for the starting point of the applicability of its provisions.

According to Art. $54 \$ 1$ of the Constitution of Greece "The electoral system and constituencies are specified by statute which shall be applicable as of the elections after the immediately following ones, unless an explicit pro-

\footnotetext{
38 Art. $51 \$ 3$ of the Constitution of Greece.

39 Official Gazette 340 A/31.12.1981.

40 Provided they are on the electoral register, unless i. they are imprisoned for a criminal offence and they have been expressly deprived of the right to vote by judicial decision, or ii. they are mentally incapable of making a reasoned judgment, according to a judicial decision.

41 For example, according to Art. $26 \$ 1$ of the Constitution of Austria, "The National Council is elected by the Federal people [...] by men and women who have completed their sixteenth year of life on the day of election". On the other hand, the reduction of the minimum voting age under eighteen (to sixteen) has been recommended by the Resolution 1826/23.06.2011 of the Parliamentary Assembly of the Council of Europe, see the Report of 18.07.2016 of the Scientific Service of the Hellenic Parliament on the Bill "Proportional representation [...]" (Law no. 4406/2016), p. 5.
} 
vision, adopted by a majority of two thirds of the total number of Members of Parliament, provides for its immediate application as of the immediately following elections" ${ }^{\prime 2}$. This means that, as a general rule, simple majority voting of an electoral law (or a law amending electoral law) leads to a postponement of its entry into force: it comes into effect in the second following election. As an exception to that rule, an electoral law could be immediately applicable (namely, in the subsequent election) only if a qualified parliamentary majority of at least two hundred votes is achieved.

A central legal question raised here concerns the scope of the meaning of the term "electoral system" used in Art. $54 \$ 1$ of the Constitution: Does it contain unanimously each law provision concerning the elections, or are there any issues that could be regulated by provisions applicable as of the following elections.

According to legal theory ${ }^{43}$, the electoral system is the set of the methods that are used in the elections, for the translation of vote totals into representative seats in Parliament. It therefore follows that other aspects of the electoral procedure (such as the composition of the electorate and technical issues of the electoral procedure) are not included within the meaning of the electoral system.

Accordingly, provisions of Law 4406/2016 ruling the methods by which votes are counted to determine the outcome of elections, such as Art. $2 \$ 1$ and 2 (which repealed the 50 -seats bonus), could be applied immediately only if a qualified parliamentary majority of at least two thirds of the total number of MPs is achieved. On the other hand, provisions of the Law 4406/2016 ruling the minimum voting age are in any case applied immediately as soon as the absolute majority of the present MPs (simple majority) ${ }^{44}$ is achieved.

42 This is a provision introduced by the Constitutional Revision of 2001 . The former Art. $54 \$ 1$ stated that "The electoral system and constituencies are specified by statute". This provision had permitted a series of electoral reforms by the governing parties which changed the electoral system a few months prior to the general election in order to get re-elected in office.

43 See E. Venizelos, op.cit, p. $477 \mathrm{ff}$.

44 See Art. 67 first sentence of the Constitution: "Parliament cannot resolve without an absolute majority of the members present, which in no. case may be less than one-fourth of the total number of the Members of Parliament" and Art. 24\$2 first sentence of the Standing Orders: "If the Constitution or the Standing Orders do not specify differently, the Plenum of the Parliament cannot decide without the absolute majority of Members of Parliament 
The aforementioned considerations reflect the procedure followed by the Hellenic Parliament while passing Law 4406/2016. Law provisions on voting age (Art. 1), which, as aforementioned, do not fall under Art. $54 \$ 1$ of the Constitution, adopted by $180 \mathrm{MPs}$. As far as it concerns any legal consequences, it makes no. difference if these provisions passed by simple or by qualified majority. In any case they would enter into force immediately.

On the contrary, Art. 5 of Law 4406/2016 provides for the immediate application of all of its other provisions (except for those referred to the voting age) under the conditions of Art. $54 \$ 1$ of the Constitution, because it constitutes the "explicit provision" referred to Art. $54 \$ 1$ of the Constitution. If Art. 5 was adopted by at least 200 MPs, then the provisions of Law 4406/2016 concerning the electoral system and constituencies would enjoy immediate application. If not, they would be effective at the next-but-one elections. Article 5 of Law $4406 / 2016$ was voted by 179 MPs. The next election in Greece, therefore, will be held under the current electoral law, namely Law 3231/2004 (as it is amended by the Law 3636/2008), and not under the election system of Law 4406/2016. The elections after the next one will be held under the election system of Law 4406/2016 (unless meanwhile a new electoral law is voted by at least 200 MPs).

As explained above, the Greek electoral system is rather complicated compared to other European countries' electoral systems. It is characterized as a «reinforced» proportional system under successive variations, more or less favorable for the majoritarian party (or the top two or three parties) and unfavorable for the small parties. It is furthermore not static; it is continually evolving in response to political and social circumstances and seeks the balance between voting equality and governmental stability.

\section{IV.}

It is a season of constitutional change the one that some European Member States are lately undergoing. The economic crisis exerted a certain influence

present. Such majority cannot be less than one fourth (1/4) of the total number of Members of Parliament" and $71 \$ 1$ of the Standing Orders: "A voting on any subject is held either by raising a hand or by standing unless the Constitution or the Standing Orders explicitly specify a different manner". 
in the debate over the constitutional revision in Greece. Since the outbreak of the crisis discussions about constitutional reform have been ongoing, although the initiation of a formal amendment process was blocked until 2013, due to the time-constraints imposed by the constitutional amending formula ${ }^{45}$. The severe institutional malfunctions detected in Greece, such as the increase of fast-track legislation, the abdication of the legislature to the advantage of the Executive, the rise of the far-right and of the far-left populist parties may not be solely considered as distinctive features qualifying the Greek case. Also in other countries of the Eurozone (Italy, Spain, Portugal) institutions experienced similar consequences without necessarily initiating a constitutional revision process.

It is indeed certain that the crisis triggered the debate over constitutional revision, as many political actors discovered themselves convinced that the Constitution was to blame for the crisis and its devastating social costs. This is clearly one way to put it and it is somehow misleading. The other is that the Greek constitution proved highly adaptable to changes, while it was the political system that collapsed, because of endemic corruption, populism and nepotism ${ }^{46}$. In the end, probably both perspectives can be equally accepted. The crisis unearthed the great demand for a change coming from the Greek society characterized more and more from a profound loss of confidence in parliamentary institutions. How this wave of dissatisfaction has been interpreted by the political actors as a mandate to initiate a radical revision of the fundamental charter of the country, where other more urgent legislative actions could have been taken without a formal amendment process is a question probably to be left unanswered ${ }^{47}$.

45 The requirement that a new revision process cannot be initiated within five years from the previous represents a characteristic feature of the Greek amending formula and a serious obstacle to constitutional innovation.

46 On the impact of the economic crisis on the Greek constitutional system, see G. Aravantinou Lleonidi, L'impatto della crisi economica sul sistema costituzionale della Repubblica di Grecia, [in:] El Impacto De La Crisis Económica en Las Instituciones de La Ue y Los Estados Miembros, eds. F. Balaguer Callejón, M. Azpitarte, E. Guillén López et J.F. Sánchez Barrilao, Thomson Reuters Aranzadi, 2015, pp. 335-377.

47 Several scholars have recently called for changes that are indeed of a constitutional character but concern the substantial and not the formal Constitution. 
The recent parliamentary adoption of the new electoral law ${ }^{48}$ has convinced the Prime Minister, Alexis Tsipras, that the time for the constitutionalisation of the proportional system is ripe and that the decision can no. longer be delayed ${ }^{49}$.

In the comparative perspective, the Greek government's decision presents some marked similarities with the Italian case, were the hot parliamentary and academic debate over the constitutional revision, now at crossroads as a referendum will be held on Sunday 4 December 2016, has been linked to the controversial electoral law, the so-called Italicum, since the draft proposal made its way in the Chamber ${ }^{50}$.

The core issues around which the political and academic debate developed in Greece are essentially: the institution of a Constitutional Court ${ }^{51}$, the provision of direct election for the President of the Republic, the strengthening

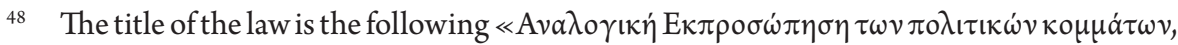

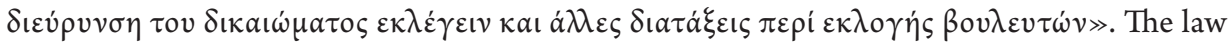

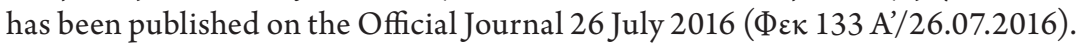

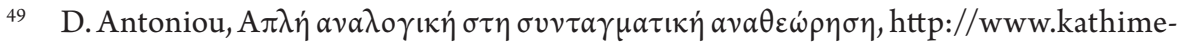
rini.gr/868328/article/epikairothta/politikh/aplh-analogikh-sth-syntagmatikh-ana8ewrhsh (9.10.2016).

50 A. Papachelas, $H a v a \theta \varepsilon \dot{\varepsilon} \rho \eta \sigma \eta \tau o v \sum v v \tau \dot{\gamma} \gamma \mu a \tau o \varsigma$, http://www.kathimerini.gr/863439/ opinion/epikairothta/politikh/h-ana8ewrhsh-toy-syntagmatos (9.10.2016).

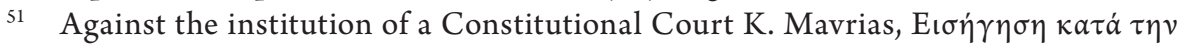

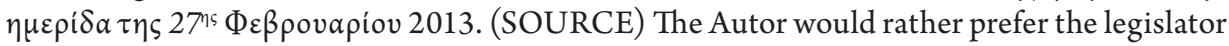
to enhance the competences of the already existing Supreme Special Court. On the organiza-

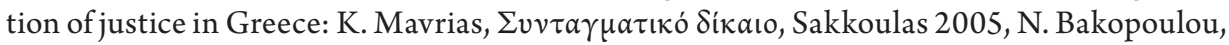

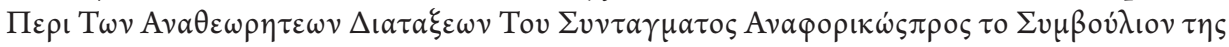

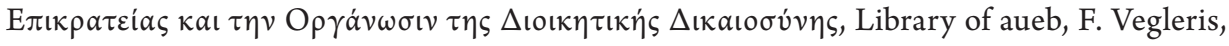
La Constitution, la loi et les tribunaux en Grèce, "Annales de la Faculté de Droit de Liège" 1967,

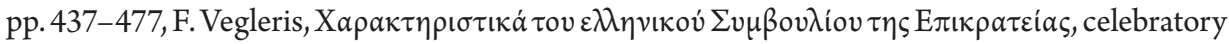

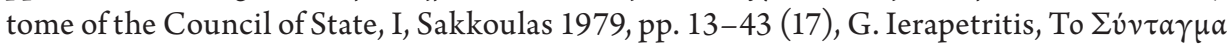

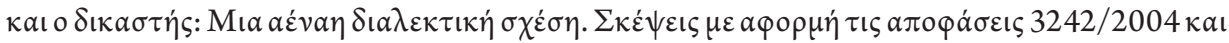

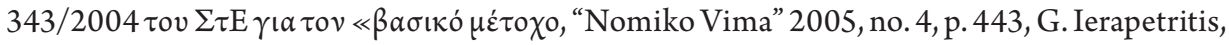

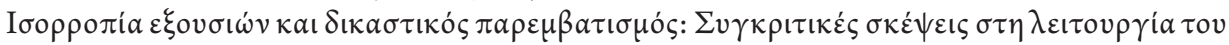

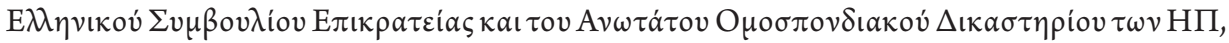

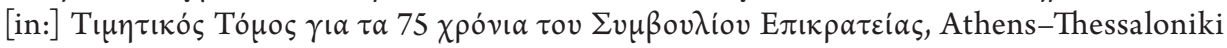

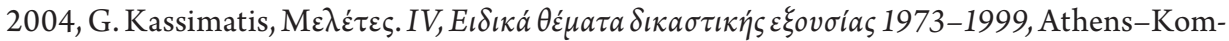

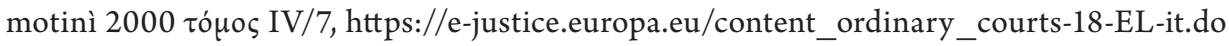
(9.10.2016), V.A. Manitakis, Fondement et légalité du contrôle juridictionnel des lois en Grèce, "Revue internationale de droit comparé" 1988, no. 1, p. 39. 
of the role of the Parliament, the strengthening of direct democracy through the introduction of the referendum as a key political instrument and finally the constitutionalisation of the electoral system. The latter proposal is a strong element of rupture with respect to the intentions of the Greek constituents who considered more appropriate to vest the power to establish the electoral system in ordinary laws rather than in the Constitution.

Before considering the merits of the proposals made by the Tsipras government, it is worth briefly to consider the constitutional provisions relating to the amending process. Any assessment of the present proposal must take into account that the Greek constitutional revision model is characterized by complex amending formulas, political-elite-driven change and difficulty in reaching compromises in constitutional issues.

The amending formula of Art. 110 sets out a series of material limits that entrench the form of government and specific fundamental rights. The first limit to constitutional revision regards the republican form of government ${ }^{52}$,

52 Similarly, the Italian constitution provides and regulates the amendment power in Section II of Title VI, allowing its exercise in respect of any provision or part of the Constitution, except for the republican form of government ideally and substantially linked to the democratic principle (Art. 138-139). Constitutional law scholars have questioned the possibility of identifying a procedure to change the republican form of government, even in the presence of the limit set by Art. 139. Costantino Mortati gave a negative answer to this question, having the amending procedure the fundamental function of keeping the Constitution alive in time, adapting it to the emerging needs, it could never subvert the system of principles and values gathered in the original layout. On the constitutional revision in Italy see V. Angiolini, Costituente e costituito nell'Italia repubblicana, Padova 1995; A. Baldassarre, Il "referendum" costituzionale, "Quaderni costituzionali" 1995; P. Barile, La revisione della Costituzione, [in:] Commentario sistematico alla Costituzione italiana, eds. P. Calamandrei, A. Levi, II, Firenze 1950; S. Bartole, Interpretazioni e trasformazioni della Costituzione repubblicana, Bologna 2004; M. Bignami, Costituzione flessibile, costituzione rigida e controllo di costituzionalità in Italia (1848-1956), Milano 1997; A. Cerri, voce Revisione costituzionale, "Enciclopedia giuridica”, vol. XXXI, Roma 1991; A. Cervati, S. Panunzio, P. Ridola, Studi sulla riforma costituzionale, Torino 2001; A. Cervati, La revisione costituzionale, [in:] AA.VV., Garanzie costituzionali e diritti fondamentali, Roma 1997; S. Cicconetti, La revisione della Costituzione, Padova 1972; G. Contini, La revisione costituzionale in Italia, Milano 1971; G. de Vergottini, Referendum e revisione costituzionale: un'analisi comparativa, "Giurisprudenza costituzionale" 1994; M. Dogliani, Potere costituente e revisione costituzionale, [in:] G. Zagrebelsky, P.P. Portinaro, J. Luther, Il futuro della costituzione, Torino 1996; C. Esposito, La validità delle leggi, Milano 1934; C. Esposito, Costituzione. Leggi di revisione della costituzione e "altre" leggi costituzionali, [in:] Raccolta di scritti in onore di Carlo 
followed by the limits related to Art. $2 \$ 1$, Art. $4 \$ 1,4$ e, 7, Art. $5 \$ 1$ and 3 , Art. $13 \$ 1$ and Art. $26 \$ 2^{53}$.

The parliamentary form of government is, therefore, an unchangeable organizing principle of the constitutional system, as well as the multi-party system and the rule of law. The amending power is vested

Arturo Jemolo, Milano 1963, III; P. Faraguna, Ai confini della Costituzione. Principi supremi e identità della Costituzione, Milano 2015; G. Ferri, Il referendum nella revisione costituzionale, Padova 2001; M. Fioravanti, Costituzione e popolo sovrano, Bologna 1998; P.G. Grasso, Potere costituente, "Enciclopedia del diritto", no. XXXIV, Milano 1985; T. Groppi, Federalismo e Costituzione. La revisione costituzionale negli Stati federali, Milano 2001; F. Lanchester, Costantino Mortati e la "Legislatura costituente", [in:] Atti del Convegno Costantino Mortati: Potere costituente e limiti alla revisione costituzionale Roma 14 dicembre 2015, "Nomos - Le attualità nel diritto” 2016, no. 1; C. Lavagna, Le costituzioni rigide, Roma 1964; M. Manetti, La deroga all'Art. 138 Cost. e la mossa del cavallo, "Rassegna. Parlamentare” 2013; M.L. Mazzoni Honorati, Il referendum nella procedura di revisione costituzionale, Milano 1982; F. Modugno, voce Revisione costituzionale, [in:] Dizionario di diritto pubblico, vol. V, ed. S. Cassese, Milano 2006; G. Morbidelli, Le dinamiche della costituzione, [in:] G. Morbidelli, L. Pegoraro, M. Volpi, Diritto costituzionale italiano e comparato, Bologna 1997; C. Mortati, Concetto, limiti, procedimento della revisione costituzionale (1952), ora in Raccolta di scritti, Milano 1972, II; A. Pace, Potere costituente, rigidità costituzionale, autovincoli legislativi, II ed., Padova 2002; A. Pace, Processi costituenti italiani 1996-1997, [in:] Studi in onore di Leopoldo Elia, II, Milano 1999; A. Pace, I limiti alla revisione costituzionale nell'ordinamento italiano ed europeo, [in:] Atti del Convegno Costantino Mortati: Potere costituente e limiti alla revisione costituzionale Roma, 14 dicembre 2015, Nomos - Le attualità nel diritto n. 1/2016; S. Panunzio, Riforma delle istituzioni e partecipazione popolare, "Quaderni costituzionali" 1992; C. Pinelli, Costituzione rigida e costituzione flessibile nel pensiero dei costituenti italiani, "Iustitia” 1980 e 1981; A. Pizzorusso, Art. 138, [in:] Commentario della Costituzione, Bologna-Roma 1981; M. Ruini, Il referendum popolare e la revisione della costituzione, Milano 1953.

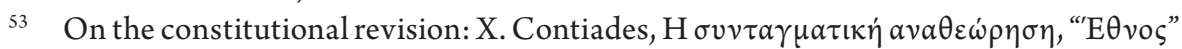

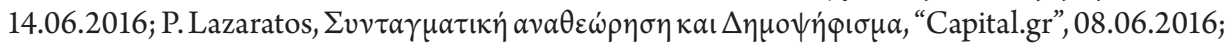

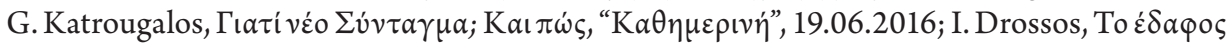

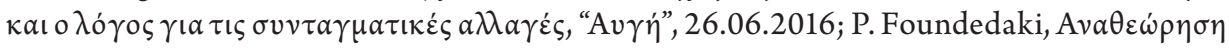

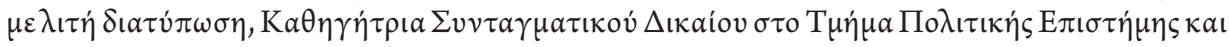

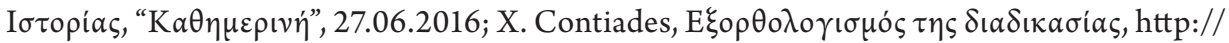
www.kathimerini.gr/870289/article/epikairothta/politikh/e3or8ologismos-ths-diadikasias

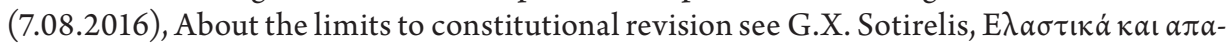

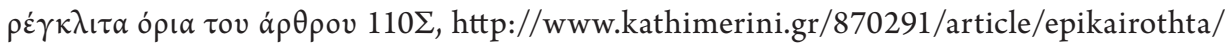

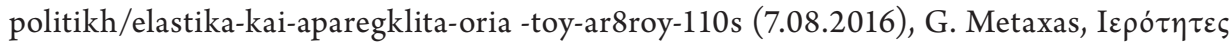

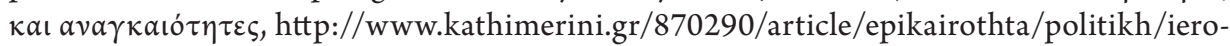
thtes-kai-anagkaiothtes (7.08.2016). 
exclusively in the monocameral Parliament and no. other constitutional body can interfere.

V.

As it has been said the amending procedure in quite complex and it is structured in two stages.

The need for a revision of the Constitution shall be established by a decision taken by the Parliament, upon the proposal of at least fifty deputies and by a majority of three-fifths of the total number of Assembly members, in two votes by roll-call held at least one month apart. The provisions that are to be revised are specifically defined by this resolution. It will then be up to the next Parliament, the so-called Revisional Parliament to proceed to the amendment of the constitutional provisions within its first term. It is worth noting that Art. 110 provides for a system of reversed majorities for the adoption of the revision proposal by the first and the second Parliament. The Constitution of 1975 introduced this system to guarantee a certain equality among the first Parliament and the Revision Parliament. In case a proposal receives the absolute majority of the members of the "Bouli ton Ellìnon" (Bov $\lambda \tau \tau \omega \nu \mathrm{E} \lambda \lambda \eta \nu \omega v)$ in the first Parliament, but not the supermajority of the three-fifths, the Revisional Parliament proceeds to the amendment of the constitutional provisions with a majority of three-fifths of its members and vice versa. Each revision of the Constitution that has been passed is published in the Official Journal no. later than ten days following the vote of the Assembly and comes into force with a special resolution of the Chamber.

The amending formula sets a mandatory time lapse between revisions, that is, revision of the Constitution is not permitted within five years of the completion of the previous one. The time-constraints set by the Constitution have been recently challenged by Greek constitutional law scholars paving the way to a new interpretative approach according to which the five-year constraint should be referred to the time before a constitutional amendment procedure is concluded and not to the pause between one revision and the other. This latest approach has gained some support especially in the aftermath 
of recent unsuccessful reforming attempts ${ }^{54}$. The rules laid down in 1975 for constitutional revision aimed to preserve the rigid character of the Constitution and to ensure the protection of the legal order. Often during the history of the Republic of Greece the complexity of the review process has triggered the worried attention of politicians and academics. This is where the recent proposals for a radical revision of the amending formula come from, raising the concern of some Greek constitutional law scholars. If on one hand scholars have not detected any constitutional obstacle to the revision of the amending formula, provided it is respected and maintained the rigid character of the 1975 Constitution, on the other hand, they haven't refrained from expressing a certain skepticism about the second part of the Government's proposal which aims to redefine the provisions not subject to revision under the first paragraph of Art.110. It is worth remembering that the complex revision process is a hallmark of the Greek Constitution with respect to the constitutions of other European countries. It reflects the particular characteristics of the political culture and the constitutional history of Greece, for this reason, any intervention that provides for radical changes should be subject to careful consideration.

Since 2013 several proposals for the revision of the Greek Constitution, most of which substantially converging, were submitted both by the majority and the opposition. This year, few days after the parliamentary vote on the new electoral law, on July 25, the Greek Prime Minister announced his proposals for a revision of the Constitution of Greece ${ }^{55}$.

Making continuous reference to what he defined as "the new transition", Alexis Tsipras, presented the SYRIZA-ANEL constitutional amendment proposal structured in five "axes": regime architecture, reinforcement of direct democracy, reinforcement of the rule of law, State-Church relations, social rights.

As for the changes affecting the form of government, the proposal entails the constitutionalisation of the proportional representation; the establishment of the constructive vote of no-confidence on the model of Art. 67 of the German

54 The Greek constitution has been revised three times in the last four decades, with the last changes coming in 2008.

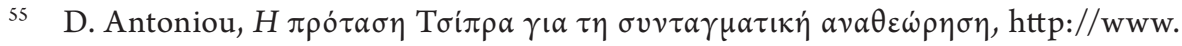
kathimerini.gr/868777/article/epikairothta/politikh/h-protash-tsipra-gia-th-syntagmatikh -ana8ewrhsh (25.07.2016). 
Basic Law (Mißtrauen im Bundestag) ${ }^{56}$; the direct election of the President of the Republic, the President would be elected by the Parliament if a qualified majority of two-thirds in two consecutive votes were reached. If these votes prove fruitless, then the people would directly elect one of the first two candidates that emerged from the parliamentary vote; the enhancement of the competences of the President of the Republic; fixed tenure for members of parliament suggesting that no. member of parliament can be elected for more than two consecutive parliamentary periods or eight consecutive years; the express provision that to be appointed as Prime Minister - with the exception of caretaking ones - one would have to be a member of the parliament.

The strengthening of direct democracy is, in fact, the second point entrenched in the proposal of the Greek government, which intends to make mandatory consultative referendums for the transfer of state functions. A major innovation is the introduction of referendums by popular initiative. A referendum on a "national issue" could be initiated by 500000 citizens; while one million signatures would be sufficient to call for a referendum to reject a bill approved by the Chamber - with the exception of budgetary bills ${ }^{57}$.

The third axis of the proposal aims to strengthen the rule of law through the establishment of a Supreme Court composed solely of judges entitled to rule on the constitutionality of a law following a proposal of the President of the Republic or 120 deputies. It also provides for the abolition of parliamentary immunities and a radical overhaul of the provisions relating to the responsibility of ministers.

Regarding the relations between the Greek State and the Orthodox Church (Art. 3 Cost.), the government's proposal provides for the formalization of state

56 Art. 67 GG: "[1] The Bundestag may express its lack of confidence in the Federal Chancellor only by electing a successor by the vote of a majority of its Members and requesting the Federal President to dismiss the Federal Chancellor. The Federal President must comply with the request and appoint the person elected. [2] Forty-eight hours shall elapse between the motion and the election". In this regard see. F. Lanchester, Le costituzioni tedesche da Francoforte a Bonn. Introduzione e testi, Milano 2009, p. 322.

57 Currently, referendums on crucial national issues may only be held following a decision of the absolute majority of parliament (Art. 44\$2). Prior to the 5 July 2015 bailout referendum no. referendum had been held in Greece since the 1975 Constitution was enacted. For a focus on the role of the people in constitutional amending processes see X. Contiades, A. Fotiadou, Participatory Constitutional Change: The People as Amenders of the Constitution, Routledge 2016. 
secularism reserving, however, for historical and practical reasons, to the orthodoxy the status of dominant religion. The text also provides for the abolition of the obligation for state officers, judges and other public officials to take an oath in the hands of the ecclesiastical authorities of the Greek Orthodox Church (Art. $59 \$ 1$, Art. $33 \$ 2$ ). The Greek Government's proposal makes some special provisions also concerning social rights expressly prohibiting lifting public management of water and energy, banning any privatization in these sectors, safeguarding collective negotiations as the only means for the definition of wages, and introducing arbitration as a mandatory means for the resolution of relevant labor disputes.

During the few weeks an intense debate has developed engaging several personalities of the political and academic world ${ }^{58}$, while waiting for the Committee that will deal with all aspects of the amending procedure to be appointed. The revision process will start with a wide consultation in all municipalities, a process not envisaged by the Constitution itself. Normally, revisions of the Constitution are handled only by the Parliament. First, discussions on constitutional amendments would be held at the municipal level with professional associations, chambers of commerce, non-governmental associations and citizens. The outcome of these discussions would be evaluated through assemblies in the thirteen regions of the country. A special website would be established to allow citizens to submit their proposals, agreements and objections.

The question here is whether the political conditions to deliver the government's revision project occur. The knots still to unravel concern, specifically, the possibility of reaching an agreement between the political forces on the strategy and the parts of the Constitution to be changed. The possibility of an agreement between the politically relevant actors has never been more distant than during the last months, because of the growing polariza-

58 The academic community has been very active in the debate over the constitutional reform. The exchanges among constitutional law professors have been hosted by the legal

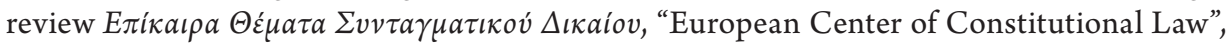

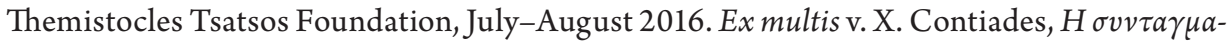
$\tau \iota \kappa \dot{\eta}$ ava $\theta \varepsilon \omega \rho \eta \sigma \eta$. The debate over the reform has crossed academic borders and reached the wider public, also thanks to the initiative promoted by a leading Greek newspapers. Among the many scholars who have spoken out on the pages of the newspaper see G. Ierapetritis,

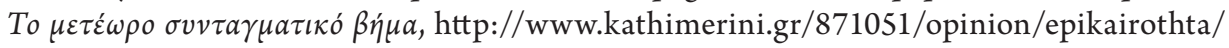
politikh/to-metewro-syntagmatiko-vhma (15.08.2016). 
tion and the creeping tension between political parties. Currently, therefore, the achievement of a general consensus on the next constitutional reform does not seem possible. The poisoned atmosphere of Greek politics, exacerbated by the severe economic crisis and the difficulties expressed by the political class in managing it, makes it bold to assume a dialogue or collaboration among political forces, highlighting the shortcomings of the constitutional culture and Greek politics. It should be up to those who now hold the majority to adopt a more conciliatory attitude so as to prevent the reform from falling on a petty conflict, losing, perhaps, an opportunity to improve the functioning of constitutional institutions. The spasmodic search of systemic stability through technical aids, changing the electoral system, as it has been recently done, or amending the constitution, has clear risks to which the Greek political system, characterized by a lack of homogeneity, does not seem, for the moment, able to expose itself without incurring in major consequences. The most recent attempts to amend the Constitution have been undertaken in the absence of a shared consensus. The process has been sponsored by a dominant political class pervaded by extemporaneous opportunism, that in an effort to annihilate the opposition loses sight of the real needs of the country, still immobilized by the grip of the economic crisis and poorly interested in the tampering of the constitutional charter masked by strengthening popular participation through a deepening of the instruments of direct democracy.

The broad scope of the proposed amendments requires, therefore, the Greek legislator to pay extreme attention to avoid the risk that the constitutional revision is reduced to a mere political diversion to ensure the permanence in power in the absence of consent and to deflect attention from continued controversial austerity policies.

\section{Literarure}

Anthopoulos Ch., The control of constitutionality of the electoral laws in Greece and the unconstitutionality of the current electoral system, "Efimerida Dioikitikou Dikaiou" 2015.

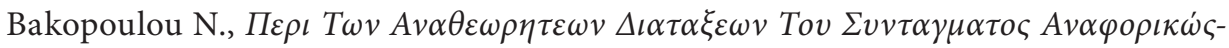

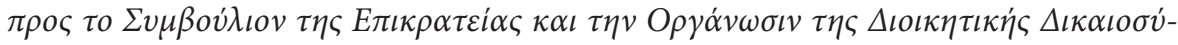
$v \eta \varsigma$, Library of aueb. 
Chryssogonos K., An introduction to Greek electoral law, http://www.cecl.gr/rigasnetwork/databank/REPORTS/r8/GR_8_Chryssogonos.html.

Chryssogonos K., Electoral system and Constitution, Athina-Komotini, 1996.

Clogg R., Greece, [in:] Democracy and Elections: Electoral Systems and Their Political Consequences, eds. V. Bogdanor, D. Butler, Cambridge 1983.

Contiades X., Fotiadou A., Participatory Constitutional Change: The People as Amenders of the Constitution, Routledge 2016.

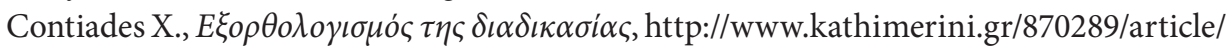
epikairothta/politikh/e3or8ologismos-ths-diadikasias.

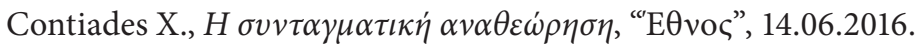

Dagtoglou Pr., Constitutional Law, Human rights, $3^{\text {rd }}$ ed., Athina-Komotini 2010.

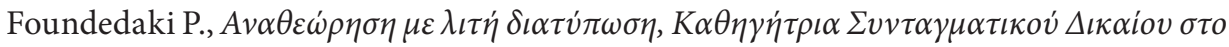

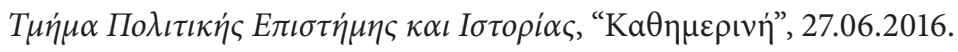

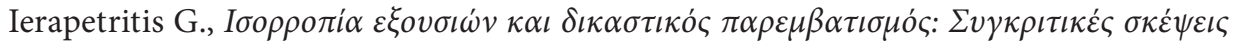

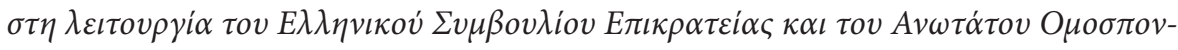

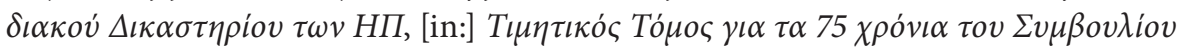

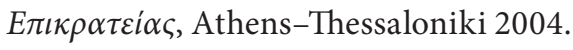

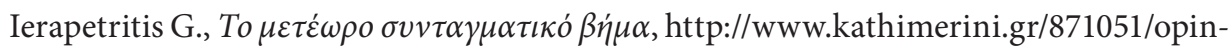
ion/epikairothta/politikh/to-metewro-syntagmatiko-vhma.

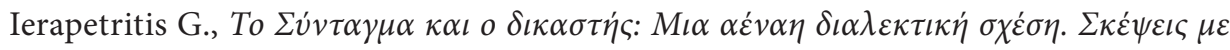

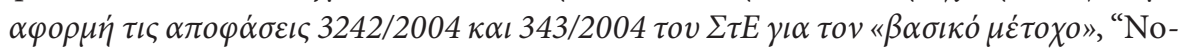
miko Vima" 2005, no. 4.

Kalogirou N., Parliamentary republic and electoral system, Athina-Komotini 1989.

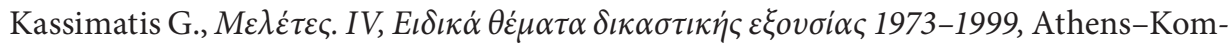

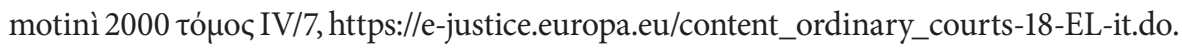

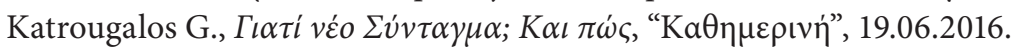

Lamprinakou C., Electoral System Change in Europe since 1945: Greece, https://www.google. $\mathrm{gr} / \mathrm{url}$ ?sa $=\mathrm{t} \& \mathrm{rct}=\mathrm{j} \& \mathrm{q}=\& \mathrm{esrc}=\mathrm{s} \&$ source $=$ web\&cd $=9 \& \mathrm{cad}=\mathrm{rja} \& u a c t=8 \& \mathrm{ved}=0 \mathrm{ahUKEw}-$ jSjZf5u83PAhVMthQKHRiIAB4QFghdMAg\&url=http\%3A\%2F\%2Fwww.electoralsystemchanges.eu\%2FFiles\%2Fmedia\%2FMEDIA_199\%2FFILE\%2FGreece_summary. docx\&usg=AFQjCNGa4TWp9XuO8KRJYLMsVZGCwotfVA\&bvm=bv.135258522,d. bGg (9.10.2016).

Lanchester F., Costantino Mortati e la "Legislatura costituente", [in:] Atti del Convegno Costantino Mortati: Potere costituente e limiti alla revisione costituzionale Roma 14 dicembre 2015, "Nomos - Le attualità nel diritto" 2016, no. 1.

Lazaratos P., $\Sigma v v \tau \alpha \gamma \mu \alpha \tau \iota \kappa \eta \dot{~} \alpha v \alpha \theta \varepsilon \dot{\omega} \rho \eta \sigma \eta \kappa \alpha \iota \Delta \eta \mu о \psi \dot{\eta} \varphi \iota \sigma \mu \alpha$, "Capital.gr”, 08.06.2016.

Lorencka M., Influence of the economic crisis on the functioning of the political systems in Greece, [in:] T. Kubin, M. Lorencka, M. Mysliwiec, Impact of economic crisis on functioning of political systems. A case study of Greece, Spain, and Italy, Katowice 2017. 
Manitakis V.A., Fondement et légalité du contrôle juridictionnel des lois en Grèce, "Revue internationale de droit comparé" 1988, no. 1.

Mavrias K., Constitutional Law, 5th ed., Athens 2014.

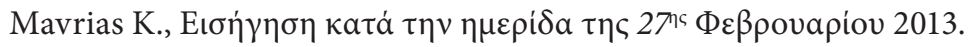

Mavrias K., $\Sigma v v \tau \alpha \gamma \mu \alpha \tau \iota \kappa o ́ ~ \delta i ́ k \alpha \iota$, , Sakkoulas 2005.

Mendrinou M., The electoral policy in the Greek political system: internal and external aspects, 1974-2000, Athina 2000.

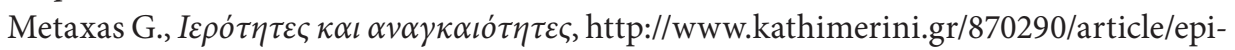
kairothta/politikh/ierothtes-kai-anagkaiothtes.

Mortati C., Concetto, limiti, procedimento della revisione costituzionale (1952), ora in Raccolta di scritti, Milano 1972, II.

Pantelis A., The Greek electoral systems and the elections (1926-1985) on the computer, Athens 1988.

Papachelas A., H $\alpha v \alpha \theta \varepsilon \omega ́ \rho \eta \sigma \eta \tau o v ~ \Sigma v v \tau \alpha \dot{\alpha} \gamma \mu \alpha \tau o \varsigma$, http://www.kathimerini.gr/863439/opinion/epikairothta/politikh/h-ana8ewrhsh-toy-syntagmatos.

Papadimitriou G., Electoral system and governance system, [in:] Electoral system and form of government, Athina-Thessaloniki 2007.

Raikos A., The control of the validity of the elections of $20^{\text {th }}$ November $1977,1^{\text {st }}$ complement of procedural electoral law, 1983.

Raikos A., The control of the validity of the elections of $22^{\text {nd }}$ Septempter $1996,6^{\text {th }}$ Complement of procedural electoral law, 1999.

Raikos A., The control of the validity of the parliamentary and European parliamentary elections, $4^{\text {th }}$ Complement of procedural electoral law, 1993.

Raikos A., The control of the validity of the parliamentary and European parliamentary elections, $5^{\text {th }}$ Complement of procedural electoral law, 1996.

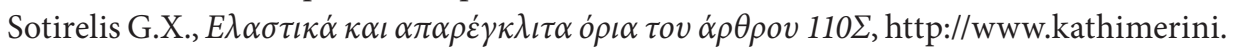
gr/870291/article/epikairothta/politikh/elastika-kai-aparegklita-oria-toy-ar8roy-110s.

Vegleris F., La Constitution, la loi et les tribunaux en Grèce, "Annales de la Faculté de Droit de Liège" 1967.

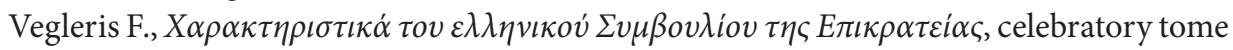
of the Council of State, I, Sakkoulas 1979.

Vegleris Ph., The particular nature of electoral law, Athina-Komotini 1992.

Venizelos E., Lessons of Constitutional Law, Athina-Komotini 2008. 